\title{
Religion in human rights law: A normative restatement
}

\author{
Tarunabh Khaitan* and Jane Calderwood Norton ${ }^{* *}$
}

In a sister article published in the preceding issue of this journal, titled 'The Right to Freedom of Religion and the Right against Religious Discrimination: Theoretical Distinctions', we focused on the theoretical differences between the right to freedom of religion and the right against religious discrimination. We explained that the right to freedom of religion is best understood as protecting our interest in religious adherence (and non-adherence), understood from the committed perspective of the (non)adherent. On the other hand, the right against religious discrimination is best understood as protecting our non-committal interest in the unsaddled membership of our religious group. This follow-up article builds upon these theoretical insights to show how key doctrinal implications follow from this distinction between our interest in religious (non)adherence and our interest in unsaddled membership of a religious group. Doctrinal implications arise for the respective scope of the two rights, whether they may be claimed against non-state actors, and their divergent tolerance levels for religious establishment. We explain that these theoretical distinctions imply that the scope of religious freedom is extremely broad, whereas that of religious antidiscrimination is relatively narrow. Moreover, religious freedom should be restricted as a claim solely against the state (or, possibly, other state-like bodies), whereas a claim of religious discrimination may be permitted against certain non-state actors as well. Thirdly, we demonstrate that certain forms of religious establishment, and other non-zerosum benefits, to particular religious groups breach the antidiscrimination guarantee but not (necessarily) the religious freedom guarantee. In the final section of this article, we map the areas of overlap between the two rights and identify cases where one of these rights might be engaged but not the other.

\section{Introduction}

There are few areas of human rights law more polarizing than religion. Controversy around protection for religion has increased as religion has reemerged in the public discourse, in a context of debates around secularism, multicultural, and feminism and LGBTQ rights. Whether it is exemptions for religion from discrimination law or accommodations made for religious practice, it is difficult for human rights lawyers not to take a position on the legal protection of religion. In this debate, the two key human rights that protect religion-the right to freedom of religion and the right against religious discrimination-are often conflated or confused. The Eweida litigation in the UK, concerning the wearing of cross in a private workplace, is a good example of this confusion. In this case, although the employee's lawyers claimed a breach of both rights against a non-state employer after she was prohibited from wearing a cross at the workplace, the emphasis at the domestic and international forums was different. Domestically, the litigation focused on religious discrimination.. ${ }^{1}$ On appeal to the European Court of Human Rights (ECtHR), the focus shifted to the right to religious freedom. ${ }^{2}$. In fact, the ECtHR explicitly held that the fact that the lower courts at the domestic level did not even have the

\footnotetext{
* Professor of Public Law \& Legal Theory at Wadham College, Oxford and ARC Future Fellow at Melbourne Law School. Email: tarunabh.khaitan@law.ox.ac.uk.

** Senior Lecturer, Faculty of Law, University of Auckland. Email: jane.norton@auckland.ac.nz.

${ }^{1}$ Eweida v. British Airways [2010] E.W.C.A. 80.

2 Eweida v. United Kingdom [2013] E.C.H.R. 37.
} 
jurisdiction to consider whether her religious freedom was engaged, did not mean "that the applicant's right to manifest her religion by wearing a religious symbol at work was insufficiently protected." ${ }^{3}$ In other words, as long as one of the two rights was considered, the demands of the other were deemed to have been satisfied. Moreover, the ECtHR applied religious freedom horizontally to the non-state employer (British Airways) - akin to how religious discrimination law operates horizontally-with no discussion as to how this new development could be justified. ${ }^{4}$. Political reactions were equally confused. Even though Eweida's claim in the ECtHR was grounded in religious freedom, the then Prime Minister David Cameron tweeted shortly afterward that he was "[d]elighted that principle of wearing religious symbols at work has been upheld-people shouldn't suffer discrimination due to religious beliefs." 5

Clarifying this confusion in the judicial and the political debate is the main motivation for this article. Read alongside a companion article in the previous edition of this journal, it offers a normative restatement of the two legal rights concerning religion, highlighting their conceptual, doctrinal, normative, and functional distinctions, as well as identifying key areas of overlap. In the previously published article, we argued that these two religious rights are in fact theoretically distinct human rights. ${ }^{6}$. Distinguishing them functionally, we explained that the right to religious freedom is best understood as protecting our interest in religious (non)adherence, whereas the right against religious discrimination is best understood as protecting our interest in the unsaddled membership of our religious group. ${ }^{7}$. Conceptually speaking, we showed that our interest in religious adherence tracks the freedom to pursue the good, whereas our interest in an unsaddled membership of a religious group tracks the good directly. At a normative level, we argued that the value of respecting decisional autonomy in matters of religious adherence underpins religious freedom, whereas the need to reduce the sociocultural, political, and material advantage gaps between different religious groups is the key aim of the right against religious discrimination.

This article builds upon the theoretical insights of the previous one. It shows how key doctrinal implications follow from the theoretical distinctions for the respective scope of the two rights, their application against non-state actors, and their tolerance of the establishment of a state religion. Before we proceed to explore these implications, two caveats are in order. First, while it is possible that these implications could also apply to non-religious interestssuch as adherence to a set of non-religious beliefs - this article's focus is on the legal protection of the freedom of religion alone. We restrict ourselves thus not because exploring "belief" is unimportant but because it requires further considerations too demanding to be met adequately in this article. Second, the goal of this article is to offer an "ideal type" normative restatement of the legal doctrine on religious rights in liberal constitutional discourse. We acknowledge

\footnotetext{
${ }^{3}$ Id., ๆ 92.

${ }^{4}$ Id., 995.

${ }^{5}$ See British Woman Wins Discrimination Case, REUTERs (January 14, 2013), available at https://www.reuters.com/article/britain-religion-court/british-woman-wins-religiousdiscrimination-case-idUSL6N0AJF9H20130115, for reporting on issue.

${ }^{6}$ Tarunabh Khaitan \& Jane Calderwood Norton, The Right to Freedom of Religion and the Right against Religious Discrimination: Theoretical Distinctions, 17(4) INT'L J. CONST. L. 1125 (2019).

${ }^{7}$ By "unsaddled" membership we mean membership that does not incur external social, economic, cultural, or political costs. Religious adherence often demands compliance with the internal rules of the religion. That group members who are also adherents of that religion will be "saddled" with these internal rules is not of concern here.
} 
that the specificities and histories of particular jurisdictions will allow some lessons to be learned but block other possibilities. This restatement isn't a manifesto-as a general theoretical restatement, its practical ambitions are necessarily modest.

In Section 2 we discuss the differences between the scope of the two rights relating to religion. Here we argue that the scope of religious freedom is extremely broad, whereas that of religious antidiscrimination is relatively narrow. Section 3 addresses the possibility of the rights' horizontal application and argues that there are good reasons why religious freedom should be restricted as a claim solely against the state (or other state-like bodies that do not themselves have a right to religious freedom), whereas a claim of religious discrimination may be permitted against certain non-state actors as well the state. Section 4 discusses the state's distribution of any non-zero-sum benefits to one religion/religious group but not another (such as the establishment of a state religion). We demonstrate that certain forms of religious establishment, and other non-zero-sum benefits, to particular religious groups breach the antidiscrimination guarantee but not (necessarily) the religious freedom guarantee. Finally, in Section 5, we map the areas of overlap between the two rights and identify cases where one of these rights is engaged but not the other.

\section{Scope of the two rights}

The first implication of the distinction we have drawn between the two religion-focused rights and the two different religious interests that underlie them-adherence and group membership-relates to the scope of the rights. Let us begin with exploring the scope of the right to religious freedom first.

In our previous article, we argued that freedom of religion is valuable because it protects our decisional autonomy in matters of religious adherence. While many other foundational values may also be good reasons to support some version of religious freedom, we argued that decisional autonomy is the only value that can fully support the capacious version of our interest in religious (non)adherence that we identified in that article. Given the need to respect decisional autonomy in matters of religion, what then is the scope of the right to freedom of religion? The short answer is that it is very wide. For the long answer, we need to first recall our three success conditions for any understanding of religion outlined in the sister article: that it should not be over-inclusive by treating my preference between (say) apples and oranges as a religious issue; that it should not be under-inclusive by privileging orthodox or majoritarian views within a religion or by privileging belief-based religions over practice-based ones; and that it should not be unfair to non-believers. We also note that the need for respecting decisional autonomy is weighty only because questions of religion (for many adherents, but also for some non-adherents) are weighty.

Translating these findings into a neat legal test is not going to be easy. It is our claim, however, that any test that accepts our rationale for protecting religious freedom is unlikely to demand more than the plausibility of the religious character of the object of the claim and the sincerity of the claimant's adherence. ${ }^{8}$. At least conceptually, the plausibility inquiry is an

${ }^{8}$ The plausibility and sincerity inquiries are already recognized in varying forms in both ECtHR and UK jurisprudence: see generally Campbell and Cosans v. United Kingdom, [1982] ECtHR (Nos. 7511/76 \& 7743/76) (February 25, 1982) (convictions have to "attain a certain level of cogency, seriousness, cohesion and importance”); R (Williamson) v. Secretary of State for Education and Employment, [2005] U.K.H.L. 15 ๆๆ 23 and 64 ("a belief must satisfy some modest, objective minimum requirements") and ("[the court] must have regard to the implicit 
intersubjective one, and the sincerity inquiry explores the committed dimension of religious (non)adherence.

The plausibility test can be stated thus: 
important, they cannot make any claims concerning other beliefs and practices that adherents of a religion can make. On the other hand, if we accord all beliefs and practices of atheists the same level of protection that religious beliefs and practices have, atheists will be protected to a far greater extent than religious adherents (for possibly everything they do might be seen as flowing from their "atheism"). Our symmetric formula, on the other hand, irrevocably ties the scope of the protection for the non-religious to that of the religious - they sink and swim together. This symmetry, and the fairness inherent in it, is a key reason why it should be accepted. Anything that $x$ has the right to be permitted to do because of his religious adherence, $\mathrm{y}$ has a right to be permitted to not do because of her non-adherence to $\mathrm{x}$ 's religion.

The plausibility test therefore ensures that the scope of religious freedom satisfies the intersubjective requirement and is therefore not overinclusive, while also being fair to nonadherents. The sincerity inquiry, on the other hand, meets our remaining success criterion by ensuring that the right is not rendered underinclusive by being subjected to any objective standards of value. It only asks: does the claimant sincerely hold that - -ing) follows from her religious adherence (including, obviously, non-adherence). This test determines the content of the claim, and is not subject to any reasonableness or communitystandard inquiry. Usual rules of evidence law should normally suffice for the purposes of the sincerity inquiry. In order to avoid an onerous and unnecessary evidentiary burden being placed on religious claimants to prove their subjective state of mind, it is better for the court to presume sincerity unless there are reasons to displace the presumption. There is no objective meritbased, centrality-based, essentiality-based, or importance-based standard -ing needs to satisfy in order to fall within the scope of the right. Autonomy demands that this be a subjective inquiry, with the inevitable implication that religious freedom potentially has a very wide and unpredictable scope.

This wide scope is in part because religious adherence makes practical demands on believers not only with regard to worship, ritual, and other forms of religious performance but potentially in every aspect of their lives. The internal point of view of religious adherents may not even recognize the religious-secular distinction. ${ }^{13}$. Religious freedom therefore casts its net very wide. What makes the scope of the freedom even broader is the question of complicity: a believer's religion may prohibit her not only from -ing but also from becoming in any way complicit in the commission of by others). For this reason, a belief that forbids the killing of animals may also require not eating meat, even if the animal was killed by another. Of course, whether such complicity is in fact prohibited by the belief in question will be subject to the sincerity and plausibility tests, but that is all. ${ }^{14}$. An adherent might believe, for example, that providing employee health insurance which has provisions for abortion or contraception could make him complicit in abortion or birth control, which his religion prohibits. One might

ECHR art. 9(1) also recognizes that freedom of religion includes "freedom to change ... religion.”

13 Alvin Esau, "Islands of Exclusivity": Religious Organization and Employment Discrimination, 33 U. BRIT. Colum. L. ReV. 719, 732 (2000); REX AdHAR \& IAN LeIGH, RELIGIOUS FREEDOM IN THE LIBERAL STATE 125 (2013) (criticizing the distinction in relation to belief and practice); Joel Harrison, Autonomy and the Liberal Imagination in Jane Calderwood Norton's Freedom of Religious Organizations, Australia J. LegAL PhiL. (forthcoming 2020), available

at https://papers.ssrn.com/sol3/papers.cfm?abstract_id=3014490.

${ }^{14}$ Cf. Douglas NeJaime \& Reva Siegel, Religious Accommodation, and Its Limits, in a Pluralist Society, in Religious Freedom AND LGBT Rights: Possibilities AND ChALlenges for FindiNG COMMON GROUND (Robin Fretwell \& William Eskridge Jr. eds., 2019). 
claim that even hiring (and paying a salary to) an employee who might use her salary to get an abortion implicates his religious freedom. The point isn't intended to be facetious. ${ }^{15}$ A potentially extremely wide and unpredictable scope for religious freedom is the inevitable consequence of adopting a largely subjective approach. But respecting decisional autonomy in matters of religion permits no other approach. Of course, this does not mean that the law will necessarily protect all these beliefs and practices - that has to be determined at the justification stage. It is, however, more honest of law, and more respectful of individuals' decisional autonomy with regard to their religious (non)adherence, to be told that other considerations necessitate a restriction on their religious freedom than to be told that what they claim is part of their religion is in fact not.

Together, the tests of plausibility and sincerity satisfy all our success conditions. The plausibility test determines whether the claim in question is within the remit of our adopted rationale-decisional autonomy in matters of religion (understood as an intersubjective phenomenon). The sincerity test allows a very wide space for autonomous decision-making within that space. A more demanding test would entail someone else (usually the state) telling an adherent what her religion in fact demands, and would therefore be incompatible with her decisional autonomy in relation to religion. ${ }^{16}$. Such objective tests would especially hurt heterodox and dissenting voices within religions, voices that most need to secure their religious freedom, and also hinder the evolution and dynamism of religions by ossifying dominant orthodox traditions.

Before we move on, a word on whether pacifism and environmentalism can have a religious character and therefore be protected by the right to religious freedom. Pacificism and environmentalism may be aspects of certain religions (many Quakers, for example, believe that their religious adherence requires pacifism), but they are otherwise unlikely to satisfy the plausibility test as such. Unlike atheistic claims whose objects have a religious character (even though the claim itself does not have a religious character), the objects of pacifist and environmental claims - qua their pacifism or environmentalism-do not have a religious character. This does not mean that they should not be protected. In bills of rights, religious freedom is usually articulated as "freedom of religion and belief," and there may well be good normative and policy reasons to protect beliefs such as pacifism and environmentalism under such rights. This article is not concerned, however, with what should populate the "and belief"

15 See First Amendment Defense Bill, H.R. 2802, 114th Cong., Session 1 (2015). The Bill sought to protect anything a person did "in accordance with a religious belief or moral conviction that marriage is or should be recognized as the union of one man and one woman'. An interpretative clause directed the judiciary to construe its provisions "in favor of a broad protection of free exercise of religious beliefs and moral convictions, to the maximum extent permitted...”. Had it been enacted, it is likely that even relatively far-fetched complicity claims would have been within its scope.

${ }^{16}$ Our claims are in sharp contrast to the practice in jurisdictions like India which only protect "essential practices" of a religion, judged by experts in those religions. In the United Kingdom, a practice will be a manifestation of religious belief only if it is "intimately linked" to that belief as judged by the court: see R (Playfoot) v. Governing Body of Millais School [2007] E.W.H.C. 1698 (Admin) at 921 (wearing of purity ring not protected by right to religious freedom because not intimately linked to religious belief in premarital chastity); $\mathrm{R}$ (Williamson) v. Secretary of State for Education and Employment [2005] U.K.H.L. 15, [2005] 2 A.C. 246, ๆ 132 , 63. By contrast, courts in the United States have refused to inquire into the "centrality" of a particular activity to a religion: Employment Div. v. Smith, 494 U.S. 872, 886-887 (1990) (Scalia, J.). 
part of the right and expresses no opinion on that matter. All we wish to do is clarify the category distinction between claims based on Judaism, Taoism, and atheism on the one hand and those based on pacifism and environmentalism as such.

In contrast with the right to freedom of religion, the scope of the right to be free from religious discrimination, according to our account, is far narrower. Under British/European law, there are two ways of showing that an act is directly discriminatory: either by showing that the act makes intentional use of a protected characteristic (such as religion) ${ }^{17}$. or by showing that there is an exact coincidence between the beneficiaries and victims of a facially neutral act on the one hand and members of a protected group and its cognates on the other (e.g. an act that burdens all the Muslims it applies to, and no one who benefits is a Muslim). ${ }^{18}$. Given the diversity of religious adherence within a religious group, it is highly unlikely that a facially neutral act will achieve such exact coincidence in the context of religious discrimination. For example, a ban on all head coverings will affect many Muslim women and many Sikh men, but it will not affect all Muslim women or all Sikh men (since, not all Muslim women wear headscarves, nor do all Sikh men wear turbans). Such a ban is therefore more likely to amount to indirect discrimination, which demands instead that the protected group be affected disproportionately.. ${ }^{19}$ In most cases of religious discrimination, an intentional use of religion as a classificatory basis (e.g. a ban on Islamic headscarves, or even a ban on all head coverings motivated by the desire to target Islamic headscarves) alone is likely to qualify as direct discrimination. ${ }^{20}$. Most other cases where members of a religious group are disproportionately burdened by a facially neutral policy will amount to indirect discrimination.

Implicit in the preceding paragraph is a key claim that needs to be brought out more clearly. The claim is that the relevant religious group should be identified sociologically from the non-committal perspective. All those who are, are associated with, or are assumed to be members of the relevant religious group are entitled to protection from discrimination based on their actual, associative, or perceived membership of that group. This claim is important because the level at which a "group" is identified for protection in discrimination law is not necessarily clear-cut. While it is true that a general ban on head coverings will not affect all Sikh men, it will affect all Sikh men who wear turbans as a religious requirement. According to this interpretation, every act that burdens religious freedom will necessarily also amount to an act of discrimination (although the reverse will still not be true). It is the premise of this article, however, that the two rights are best understood to be performing distinct functions in human rights adjudication. The difficulty with identifying the relevant religious group with reference to adherence is that it blurs the boundaries between the two rights: it fails to take the distinction between a person's committed interest in religious (non)adherence and her noncommittal interest in her religious group membership sufficiently seriously. It also fails to adequately take notice of the different normative foundations of the two rights. Furthermore, an adherence-based, rather than a sociological understanding of a religious group, will leave those perceived to be members of the group - even if they do not adhere to its religionwithout the protection of discrimination law. After all, an atheist whose job application is rejected on the basis that she has a Jewish-sounding name is as much a victim of religious discrimination as one who is in fact committed to Judaism. For all these reasons, it is essential

\footnotetext{
${ }^{17}$ CHEZ Razpredelenie Bulgaria AD v. Komisia za Zashtita ot Diskriminatsia (2015) Case C83/14 (E.C.J.), [2015] I.R.L.R. 746, ๆף 75, 76, 95.

${ }^{18}$ Bull v. Hall [2013] U.K.S.C. 73, [2013] 1 W.L.R. 3741, ๆ 19.

${ }^{19}$ Griggs v. Duke Power Co., 401 U.S. 424 (1971); Essop v. Home Office (UK Border Agency) [2017] U.K.S.C. 27.

${ }^{20}$ See Bougnaoui v. Micropole SA (2017) Case C-188/15 (E.C.J.).
} 
for the purposes of discrimination law that the relevant religious group should be identified sociologically from the non-committal perspective, rather than with reference to individual religious adherence. ${ }^{21}$. The implication of this claim is that the threshold required to be satisfied in order to make an antidiscrimination claim is relatively high.

\section{Relationality}

The second implication of the distinction we have drawn between the two rights concerns relationality. Human rights are typically considered to be claims against ("vertical") infringements by the state. It is accepted that the state may not, without adequate justification, infringe upon one's freedom of religion or discriminate against anyone on the ground of religion. The controversial question is whether, and to what extent, these rights should be treated as claims in private ("horizontal") relationships. This section explores this issue. To be clear, we do not take the public person/private person distinction to be a rigid one. We accept that between the spectrum-defining end points of the state and a natural individual lies a whole range of bodies with different degrees of publicness. ${ }^{22}$

We also note that the horizontality-verticality distinction does not completely capture various dimensions of relationality pertaining to the operation of a right. Even if a right does not have horizontal application, this does not mean that it has no role to play in defining private relationships. In order to appreciate what we are going to say in regard to relationality fully, it is helpful to first revisit Hohfeld's famous analysis of rights in terms of how they structure relationships between persons. Hohfeld showed that legal rights were not some "things" out there but a type of relationship between persons. Furthermore, the language of "rights" was ambiguous, and could refer to any of four different types of relationships: liberty, ${ }^{23}$ claim, ${ }^{24}$ power, and immunity. Table 1 provides a brief, jargon-laden snapshot of Hohfeld's categories.

Table 1.

\begin{tabular}{|c|c|c|}
\hline & Jural Opposites & Jural Correlatives \\
\hline \multirow[t]{2}{*}{$\begin{array}{l}\text { Primary } \\
\text { concepts }\end{array}$} & $\begin{array}{l}\text { If A has a claim, then A lacks a no- } \\
\text { claim. }\end{array}$ & If A has a claim, then B has a duty. \\
\hline & $\begin{array}{l}\text { If A has a liberty, then A lacks a } \\
\text { duty. }\end{array}$ & $\begin{array}{l}\text { If A has a liberty, then B has a no- } \\
\text { claim. }\end{array}$ \\
\hline \multirow[t]{2}{*}{$\begin{array}{l}\text { Secondary } \\
\text { concepts }\end{array}$} & $\begin{array}{l}\text { If A has a power, then A lacks a } \\
\text { disability. }\end{array}$ & $\begin{array}{l}\text { If A has a power, then B has a } \\
\text { liability. }\end{array}$ \\
\hline & $\begin{array}{l}\text { If A has an immunity, then A lacks a } \\
\text { liability. }\end{array}$ & $\begin{array}{l}\text { If A has an immunity, then B has a } \\
\text { disability. }\end{array}$ \\
\hline
\end{tabular}

${ }^{21}$ The UK Court of Appeal conducts a similar analysis to determine whether a no-neck-jewelry policy disproportionately impacts cross-wearing Christians: Eweida v. British Airways Plc. [2010] E.W.C.A. Civ. 80 9ף 18-19. Although the ECtHR disagreed with the outcome of the judgment, it did so on religious freedom grounds rather than on a religious discrimination basis. ${ }^{22}$ See TARUnABH Khaitan, A THEORY OF Discrimination LAW ch. 7 (2015).

${ }^{23}$ Hohfeld called this "privilege," but liberty is generally accepted as a better term in the Hohfeldian literature.

${ }^{24}$ Again, Hohfeld referred to this concept as a "right," but that could lead to confusion between the subcategory and the broader category he was disambiguating. The literature now mostly sticks to "claim" as a better descriptor of what he intended. 
It is unnecessary to explain these well-known categories in detail. The most important distinction, for our purposes, is the one between a liberty and a claim

-ing. When I have a liberty to

you have a claim

not

I am therefore not at

Some examples should clarify the complex Hohfeldian definitions of these concepts. In a jurisdiction that has a finders-keepers law, I am at liberty to pick up an unclaimed \$10 note lying on a public footpath. Suppose that you and I see the note at the same time, but you are quicker than I am and pick it up before me. Although I had a liberty to pick it up before you did, after you have done so, I am no longer in a position to exercise that liberty. Moreover, I have no claim against you. The situation is likely to be different if the note was found on my property. In this case, the law is likely to recognize my claim over the note found on my property against you. You would likely have a duty to give me the note. Take another example: I am at liberty to speak but I do not-normally-have any claim against you to listen to what I have to say. In certain circumstances, however, I may well have a claim to be heard, for example, by a court which is trying me for an offense. A final example: in most liberal jurisdictions, I am at liberty to have consensual sex with any other adult person. But I have no claim against any other person to have sex with me (although some jurisdictions still recognize the concept of conjugal rights, which grants a person a claim to have sex with their spouse). It should be clear by now that a horizontally applicable "right" gives me a Hohfeldian claim against you. But even if the right is only a mere liberty (between private persons), and therefore lacks a horizontal dimension, it does not mean that its operation is irrelevant to how private

exercise in certain permitted ways (e.g. by picking up the dollar bill before me). But that person may not prevent me from exercising it, or visit any penalty on me for my having exercised it (whether directly or by using the law's coercive power). These examples bring out another feature of the distinction: whether a legal system treats a right as a liberty or a claim is a normative choice that it makes. It is not a matter that conceptual analysis can settle. ${ }^{25}$. The issue before us is how the two rights (both of which are claims against the state) should structure relations between private persons. We will show that the law's treatment of the right against religious discrimination as a (limited) claim between private persons is justified, but that the right to religious freedom should remain a liberty in private contexts.

Let us first consider why a right to religious freedom should remain a liberty in private contexts. Recall our plausibility test for determining whether a person is claiming an interest in religious (non)adherence:

reasonable person sufficiently familiar with the X's socio- $\quad$-ing has a religious character."

Under our symmetric approach (designed to respect the decisional autonomy of the religious adherent and the non-adherent), if -ing must have could be met with an opposite

claim -ing by X. So, a claim by a Hindu man that the eating of beef by non-Hindus breaches his religious freedom will always face a potential reply from a nonHindu beef eater who does not wish to be subject to Hindu religious norms. The problem can

${ }^{25}$ See Stephen Hudson \& Douglas Husak, Legal Rights: How Useful Is Hohfeldian Analysis?, 37 PhIL. STUD.: AN INT’L J. FOR PHIL. IN ANALYTIC TRADITION 45 (1998). 
be avoided only if Y herself does not possess the right to religious freedom-which is true for the state (and any other persons like the state) but not true for private individuals.

It could be argued that religious freedom could still be treated as a claim rather than a liberty. This is because the same claim made on either side of a dispute would lead to their mutual cancellation only if the two claims are of equal weight. A judicial balancing of the opposite claims could, in theory, evaluate their respective weight, intensity, or centrality. These inquiries, however, would require judicial interrogation of the internal and subjective dimensions of religious (non)adherence-something that, according to our approach, would be inimical to religious freedom and should be avoided as far as possible. It is better therefore if religious freedom is treated, in the context of private relationships, as a liberty rather than a claim. In fact, this normative insight might hold for most rights that track our interest in the freedom to pursue the good (as opposed to rights that directly track our interest in the good). ${ }^{26}$

The right against religious discrimination does not suffer a similar difficulty concerning simultaneous but opposing claims. First, while it is theoretically possible for both parties to a dispute to have a simultaneous claim of religious discrimination against each other arising out of the same set of facts, these cases are likely to be rare. ${ }^{27}$. Whatever little possibility there might have been for such cases to exist is obviated by the fact that in most common law jurisdictions, the duty to not discriminate applies only in specified spheres of quasi-public activities (such as employment, housing and retail) and flows unidirectionally (i.e. from the landlord to the tenant, for example, but not the other way around). The limited horizontality of discrimination law is justified not because of claims that cancel each other out but for other reasons that need not concern us here. ${ }^{28}$. Even if, somehow, one ends up with a case with mutually antagonistic antidiscrimination claims on both sides, since these claims are founded upon public, non-committal viewpoints, there is no reason for the state to refrain from adjudicating upon their respective merit, cogency, weight, and so on. For this reason, horizontal application of discrimination law does not pose institutional challenges comparable to those posed by that of religious freedom.

Religious freedom should remain a liberty, at least in cases where both parties possess the right to religious freedom. Whether it can be a claim against other state-like bodies (perhaps like very large corporations) that lie in between the state and natural individuals would depend on whether these non-natural persons possess the right to religious freedom. ${ }^{29}$. We will leave this thorny question for another day.

\section{Non-zero-sum benefits, expressive harms, and religious establishment}

The third key distinction between freedom of religion and the right against religious discrimination is with regard to attitude to non-zero-sum benefits. Non-zero-sum benefits to any one religion/religious group do not violate religious freedom, but they do discriminate.

\footnotetext{
${ }^{26}$ See KHAITAN \& NORTON, supra note 6, $1135 \mathrm{f}$.

${ }^{27}$ It is also difficult to think of examples of cases where both parties have simultaneous claims of discrimination against each other on different grounds. Even in Bull v. Hall, where Christian Bed and Breakfast owners who refused to give a double bedroom to a gay couple complained of religious discrimination, they did so against the state, and not against the gay couple. See Bull v. Hall [2013] U.K.S.C. 73.

${ }^{28}$ For details on these reasons, see KHAITAN, supra note 22, ch. 7.

${ }^{29}$ See Burwell v. Hobby Lobby, 134 S. Ct. 2751 (2014). The ECtHR in Eweida applied it as a claim against a large corporation - this may well be justified, but it needs cogent reasons that the court failed to provide: see Eweida v. United Kingdom, 57 Eur. H.R. Rep. 8 (2013).
} 
Non-zero-sum benefits are benefits that are given to the adherence of any one religion that do not burden adherence to other religions. Examples of such benefits include a provision for a special subsidy to Muslims who wish to undertake the Haj pilgrimage, for a Christian chapel at the workplace, or for the establishment of Buddhism as the state religion. These benefits are non-zero-sum, at least in the material sense, because while they benefit the adherence of one religion, they do not - on their own - burden adherence to any other religion or to no religion at all. Provision for a Haj subsidy does nothing to constrain a devout Hindu's ability to adhere to her religion. These non-zero-sum benefits, we argue, do not infringe the religious freedom of non-adherents of the religion being benefited. There may well be (and, we will shortly argue, there indeed are) good reasons why the state should avoid selectively benefiting adherence to certain religions, but the protection of religious freedom is not one of them. This argument follows from our underlying rationale for religious freedom - there is nothing in non-zero-sum benefits for adherence to a religion that, on its own, affects a person's decisional autonomy with respect to her own (non)adherence.

Two objections might be raised against our claim that non-zero-sum benefits do not affect the religious freedom of non-adherents. First, it might be argued, that benefits for the chosen religion, even if non-zero-sum, would incentivize adherence to it (at least by those motivated more by worldly benefits than by their ultimate salvation). While this may be true, recall that our decisional autonomy-based account is highly subjective and protects religious adherence of the intense and the frivolous and does not interrogate one's motives for adherence (as long as the adherence itself is sincere and not a sham). If so, there is no cost to decisional autonomy unless an adherent's will is interfered with through coercion or manipulation. A zerosum benefit to adherents of another religion, on its own, is unlikely to amount to such interference, even if these benefits make it more attractive to potential converts. That said, if the non-zero sum benefits concern a basic good or a basic right, making their access conditional on adherence to a particular religion would amount to coercion, and therefore breach religious freedom. Thus, religion-based provision of citizenship or basic education is likely to burden the religious freedom of the non-adherent, because the denial of these basic goods to them (unless they convert) amounts to coercion.

A second objection might be that even though non-zero-sum benefits to adherents of one religion do not materially burden non-adherence of that religion, might they not burden it expressively? ${ }^{30}$. Does not the establishment of Buddhism, for example, as the state religion express the state's recognition of its superiority over other religions? It is true that non-zerosum benefits to religious adherence may well entail such expressive messages. However, legal recognition that religious freedom can be infringed by expressive harm alone would be destructive of the guarantee of religious freedom itself. Such recognition would undermine the religious freedom of non-adherents to freely criticize, reject, and even condemn the religions they do not adhere to. After all, as we have seen, a capacious understanding of religious freedom founded upon the importance of decisional autonomy, protects adherence as well as non-adherence. Just as it protects the intense as well as the relaxed adherent, it must also protect the tolerant as well as the incensed non-adherent. Comparable to the difficulty with horizontal

${ }^{30}$ An argument of this type was made by Justice O’Connor in Lynch v. Donnelly, 465 U.S. 668 (1984) ("Endorsement sends a message to nonadherents that they are outsiders, not full members of the political community, and an accompanying message to adherents that they are insiders, favored members of the political community") and Justice Sachs in S. v. Lawrence 1997 (4) S.A. 1176 (CC) (S. Afr.) (“negative radiating symbolic effect”). 
enforcement of religious freedom, recognition of expressive or symbolic harms as burdens on religious adherence could undermine religious freedom itself.

Even if one accepts the argument in the preceding section, could the prohibition on inflicting expressive harm on religious adherence be confined to the state? Surely, the state itself does not have a claim to freedom of religion? That much is true. However, while it is certainly desirable that state officials do not condemn any religion, certain specific religious requirements will frequently come into conflict with state policy or public morality-an acrossthe-board prohibition of expressive harms, even when applied to the state alone-is not without problems, especially in light of the very wise scope of the right to religious freedom. This is especially so if one adopts an objective standard for determining expressive harms, i.e. when the symbolic insult to the religion is judged not based on the intention behind the symbolic act but its public meaning. For this reason, it is best to keep expressive harms outside the remit of what counts as "burdening" religious adherence. According to this view, religious establishment, on its own, may well be compatible with religious freedom for all, as long as it does not entail the exclusive denial of access to any basic goods to any non-adherents of the established religion. ${ }^{31}$

On the other hand, benefits to the membership of a religious group to the exclusion of others, whether zero-sum or non-zero-sum, paradigmatically constitute discrimination. While religious adherence needs to be burdened in absolute terms for one's religious freedom to be infringed, members of a religious group need only be disadvantaged comparative to another group for the act to qualify as discriminatory. While there is some debate in discrimination law over whether non-comparative harms to a protected group amount to (prima facie) discrimination, there is no debate over the fact that comparative harms always do. It may be that no employee is entitled to a bonus, but if a company pays a bonus to all its Christian employees but denies it to all others, it would constitute a clear case of discrimination. Discrimination law has also come to register exclusively expressive harms as discriminatory too. ${ }^{32}$

None of this is surprising if we bear the underlying function of discrimination law in mind: to reduce and to ultimately eliminate (pervasive, abiding, and substantial) relative group disadvantage. ${ }^{33}$. As we pointed out in our previous article, almost all credible accounts of this area of law accept that the current or historical disadvantage faced by social groups lies at the heart of discrimination law. ${ }^{34}$. This means that discrimination law, at its most fundamental level, cares for how groups fare relative to each other, in material, political, and sociocultural terms (although, it does so only because that has a non-relative impact on the success of the lives of individual members of the relatively disadvantaged group). Thus, even non-zero-sum benefits and expressive harms suffice to trigger a discrimination claim.

Each of the three examples of non-zero-sum burdening of adherence we gave abovepilgrimage subsidy, workplace chapels, and religious establishment-benefit not just adherence but also group membership. While we argued that none of them-without moreis likely to violate religious freedom, we also think that each of them is a textbook instance of

${ }^{31}$ See Rex Ahdar \& Ian Leigh, Is Establishment Consistent with Religious Freedom?, 49 MCGILL L.J. 635 (2004).

${ }^{32}$ See Tarunabh Khaitan, Dignity as an Expressive Norm: Neither Vacuous nor a Panacea, 32 OXFORD J. LEGAL STUD. 1 (2012).

${ }^{33}$ KHAITAN, supra note 22, ch. 5.

${ }^{34}$ See Khaitan \& Norton, supra note 6, $1141 \mathrm{f}$. 
prima facie direct discrimination on the ground of religion. The reason should be obviousnon-zero-sum benefits may not violate religious freedom, but they do discriminate.

\section{Overlaps between the two rights}

Thus far we have been arguing that the two religion rights-religious freedom and freedom from religious discrimination-are distinct human rights and, as such, protect distinct human interests and distinct (although sometimes overlapping) aspects of religion. Highlighting their distinctiveness does not deny significant overlaps in their scope. Based on the normative restatement of the legal doctrine we have provided so far, Table 2 illustrates how these rights protect distinct aspects of religion.

Table 2

\begin{tabular}{|c|c|c|c|c|}
\hline & & & Intentional & Unintentional \\
\hline \multirow{4}{*}{$\begin{array}{c}1 . \\
\text { Affecting } \\
\text { adherence }\end{array}$} & \multirow{2}{*}{$\begin{array}{l}\text { 1.1 Non-zero- } \\
\text { sum } \\
\text { benefiting }\end{array}$} & 1.1.1 State & A1 (DDRF) ${ }^{\mathrm{a}}$ & A3 (ID?RF) ${ }^{b}$ \\
\hline & & 1.1.2 Private & A2 (DDRF) ${ }^{\mathrm{C}}$ & A4 (ID?RF) ${ }^{d}$ \\
\hline & \multirow{2}{*}{$\begin{array}{l}1.2 \text { Burdening } \\
\text { or zero-sum- } \\
\text { benefiting }\end{array}$} & 1.2.1 State & $\mathrm{B} 1$ (DDRF) $^{\mathrm{e}}$ & B3 (ID?RF) ${ }^{f}$ \\
\hline & & 1.2.2 Private & B2 (DDRF) ${ }^{\mathrm{g}}$ & B4 (ID?RF) $)^{h}$ \\
\hline \multirow{2}{*}{\multicolumn{2}{|c|}{$\begin{array}{l}\text { 2. Affecting group } \\
\text { membership }\end{array}$}} & 2.1 State & C1 (DD; RF?) ${ }^{\mathrm{i}}$ & C3 (IDRF) $)^{j}$ \\
\hline & & 2.2 Private & C2 (DDRF) ${ }^{\mathrm{k}}$ & C4 (IDRF) ${ }^{1}$ \\
\hline
\end{tabular}

a See, e.g., Lautsi v. Italy, App. No. 30814/06, Eur. Ct. H.R. 2412 (2011), 54 Eur. H.R. Rep.

3 (2012) (cross in public school classroom) and establishment cases from the United States such as Van Orden v. Perry, 545 U.S. 677 (2005) (public display of Ten Commandments). Here the state provides a non-zero-sum benefit to one religion/group but not to others.

$\mathrm{b}$. An example of unintentionally benefiting adherence to a particular religion in a non-zerosum manner would be a preference in public employment for candidates who know more than one language, assuming that this is likely to disproportionately benefit Orthodox Jews and Muslims who know Hebrew or Arabic for religious reasons.

c Provision of an Anglican chapel at a private workplace would be an example of a non-zerosum benefit to the adherence of one religion.

d A university that has a flexible holiday policy for academic staff would disproportionately benefit adherence to those religions that require a religious pilgrimage on specific dates. Such a policy, however, would almost certainly satisfy any proportionality-based justification threshold in indirect discrimination law.

e Examples would include state prohibition of the Muslim headscarf or kosher slaughter (shechita).

f For examples of unintentional burdening of religious adherence, see Employment Div., Dep’t of Human Res. of Oregon v. Smith, 494 U.S. 872 (1990) (a prohibition on the consumption of peyote); R (Ghai) v. Newcastle City Council [2011] Q.B. 591 (a prohibition on the outdoor cremation of a dead body); Alberta v. Hutterian Brethren of Wilson Colony, [2009] 2 S.C.R. 567 (Canada) (a requirement that driver licences include a photo).

g E.g., a private employer banning its employees from wearing the Muslim headscarf.

h Examples of B4 include a private employer's workplace dress code that prohibits wearing of all head coverings or jewelry. 
i E.g., a state that has different classes of citizenship or imposes differential levels of taxes depending on religion.

j.- See, e.g., Naeem v. Secretary of State for Justice [2017] U.K.S.C. 27 where it was found that Muslim chaplains were at a disadvantage in the pay scale because of their shorter lengths of service (the Prison Service having not employed Muslim chaplains on a salaried basis until 2002).

$\mathrm{k}$ An example here might be an employer who refuses to interview an applicant because he or she has a Jewish surname.

${ }^{l}$ E.g., a requirement that a high school diploma is needed for higher-paid positions, which then results in members of certain religious groups being disqualified at a substantially higher rate than members of other groups (a "religious” Griggs case: Griggs v. Duke Power Co., 401 U.S. 424 (1971)).

In row 1 of Table 2, we map the various ways in which religious adherence may be interfered with. Row 1.1 tracks non-zero-sum benefits (not amounting to basic goods or basic rights) for religious adherence by state and private persons. Row 1.2 captures other forms of interference with religious adherence. Applying what we learned in Section 4, no interference by a private actor amounts to a breach of religious freedom (RF in rows 1.1 .2 and 1.2.2). However, such acts - if intentional—would amount to prima facie direct discrimination (DD) if the private actor is one regulated by discrimination law, and may amount to prima facie indirect discrimination if the act is unintentional but disproportionately impacts a religious group (ID?). When the actor is the state, the conclusions with regard to discrimination are similar in rows 1.1.1 and 1.2.1.

Although we have suggested that intentional cases of burdening religious adherence in row 1.2, whether by the state or a private person, will be prima facie direct discrimination, one qualification is needed-it is possible to have a case where all forms of religious (non)adherence were burdened. ${ }^{35}$. In such cases, it is possible that there is no direct discrimination. Even in such cases, it is highly unlikely that all forms of religious adherence will be burdened equally —if some forms are burdened disproportionately over others, a prima facie case of indirect discrimination could still be made.

As we know from the preceding section, if the state interferes by providing non-zerosum benefits (not concerning basic goods) for adherence to any particular religion, religious freedom is not violated (RF). The only prima facie breaches of religious freedom in row 1 happen under 1.2.1, where the state interferes either by burdening or by providing a zero-sum benefit for religious adherence.

When the action affects group membership, rather than adherence, in relevant ways (row 2), it is prima facie discriminatory by definition. Of the various possibilities, it is only where the state intentionally discriminates that is it possible that religious freedom may also be breached. Take, for example, a law that denies voting rights to the members of a certain religious group. Even though being able to vote is (let us assume) not required for adherence to that religion, a directly discriminatory law affecting such a basic right has clear implications for religious adherence as well. Each category in Table 2 has a distinct example that cannot be placed in any other category. Figure 1 shows a different way to visualize these overlaps.

${ }^{35}$ Achbita v. G4S Secure Solutions NV (2017) Case C-157/15 (E.C.J.), was arguably one such case. For a critique of the decision see Lucy Vickers, Achbita and Bougnaoui: One Step Forward and Two Steps Back for Religious Diversity in the Workplace, 8 EUR. LAB. L.J. 232 (2017). 


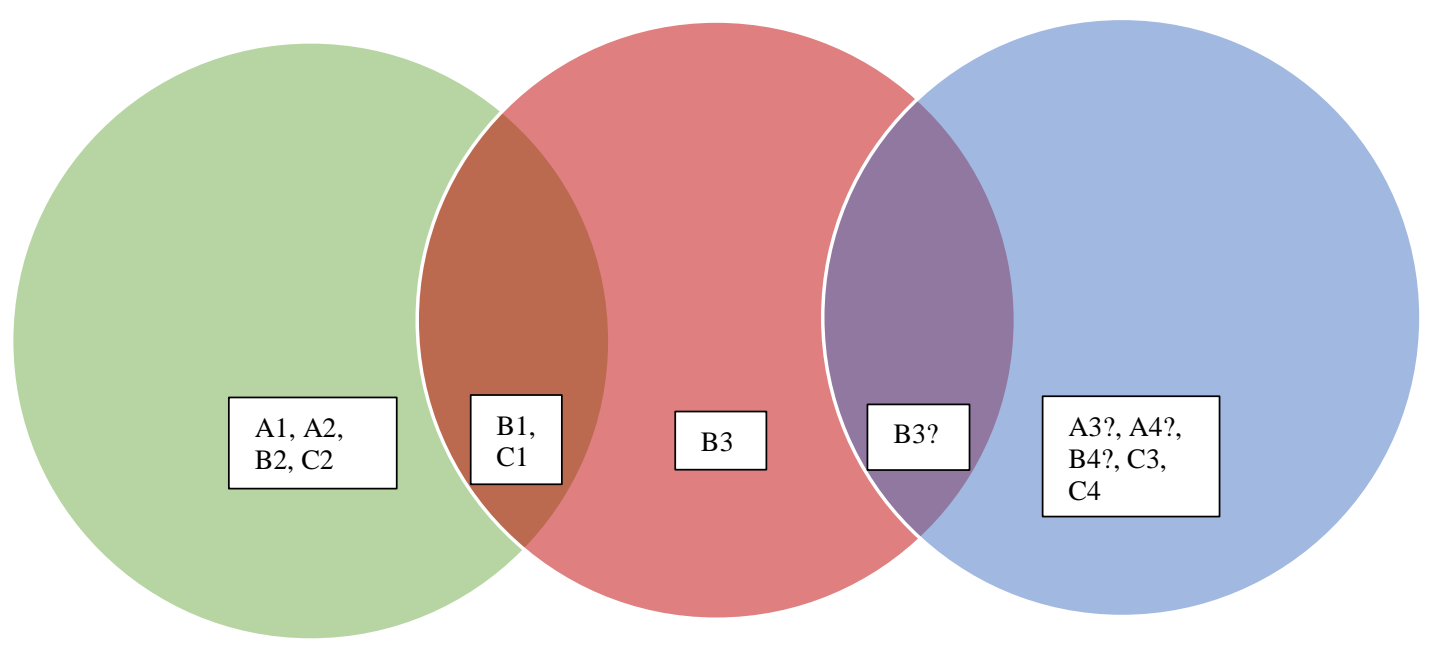

We know that direct discrimination and indirect discrimination are mutually exclusive. Cases that amount to prima facie direct discrimination but do not engage religious freedom (green part of the first circle on the left) include A1, A2, B2, and C2. Cases that are prima facie indirect discrimination but not a prima facie breach of religious freedom (light blue part of the circle on the right) include C3 and C4, and potentially A3, A4, and B4 (depending on whether the disproportionate impact standard is satisfied). Possible overlap between direct discrimination and religious freedom occurs in cases such as B1 and C1, whereas possible overlaps between indirect discrimination and religious freedom include cases under B3. B3 cases that fail to satisfy the disproportionate impact standard of indirect discrimination liability constitute the residual red part of the middle circle.

We have explained how the two religion rights-religious freedom and freedom from religious discrimination — are distinct human rights that protect distinct human interests and distinct aspects of religion. These aspects of religion can, of course, overlap but we have illustrated in Table 2 and Figure 1 how there remain distinct areas with no overlap.

Given that these two rights protect distinct human interests and distinct aspects of religion, whether and how their infringement may be justified can differ. Both rights under consideration-freedom of religion and the right against religious discrimination-are qualified rights that admit to the possibility of justification. ${ }^{36}$. This is not unusual as few human rights are absolute. Most tend to be qualified rights, in the sense that their infringement may occasionally be justified for sufficiently weighty countervailing reasons. Different jurisdictions characterize the justification analysis differently (with proportionality being the most popular analytic frame). Most, however, consider factors such as the weight of and impact on the interests/rights of both parties and the public interest involved, the nexus between the impugned

${ }^{36}$ It is true that in statutory contexts governing private relationships, certain forms of discrimination are treated as not justifiable. But in constitutional law, the right against discrimination almost always admits to the possibility of justification, even though sometimes the threshold for realizing that possibility might be extremely high. 
act and the end it seeks to achieve, and the judiciary's relative institutional capacity and expertise in second-guessing the political decision under challenge. Given our position on relationality - that the right against religious discrimination is only a limited claim between private persons and that the right to religious freedom is a liberty, not a claim, in private contexts - the comments in this section apply only to the justification of state action that infringes upon either of the two rights.

We turn first to infringement of the right against religious discrimination. When a claimant has made a prima facie case of religious discrimination, the intensity of judicial scrutiny is typically very high. ${ }^{37}$. This is because religious group membership is not only normatively irrelevant to most state actions, it is also descriptively irrelevant. In other words, not only should the state not act based on a person's membership of a religious group when it adversely affects vulnerable groups, religious group membership is rarely connected rationally with any legitimate state goal. In fact, its entanglement with state action often reflects prejudice against, hostility toward, stereotyping of, or indifference to the needs of religious minorities. Direct and even indirect discrimination often (although not necessarily) captures these impulses. ${ }^{38}$ This is why a presumptive judicial suspicion of prima facie cases of religious (and, indeed, other forms of) discrimination is justified. It is true that the use of religious group membership as a basis for state action may be justified even outside the context of affirmative action-however, such cases will be rare for direct religious discrimination.

In indirect discrimination cases, where a neutral action disproportionately affects a religious group, ${ }^{39}$ the possibility of justification is likely to depend on contextual factors that usually inform the proportionality analysis (such as the respective weight of the state's and the claimant's interests and the extent to which they are harmed or served by the proposed action). The non-committal interest in not having one's religious group suffer disadvantage is readily cognizable by courts - it is the sort of thing that a public judicial perspective can grasp and evaluate alongside the interests of the state and any third parties.

Determining the justifiability of an act that infringes upon religious freedom, on the other hand, is generally more difficult. The degree of difficulty will vary depending on whether the two rights overlap. Admittedly, some cases are easy. Often religious freedom is violated because of prejudice against, or hostility toward, a particular religion. Such tainted cases will be unjustified even under the most deferential judicial scrutiny, and in any case are also likely to amount to unjustified direct religious discrimination. In fact, the problem of the appropriate standard of review for religious freedom cases does not matter, at least in practical terms, for all overlap cases where both rights are engaged. Wherever we peg the judicial standard of review for religious freedom cases generally, it is unlikely to be higher than the very high standard of review in discrimination cases. In overlap cases, therefore, if religious

\footnotetext{
${ }^{37}$ In keeping with the practice of most jurisdictions outside the United States, we are assuming that affirmative action measures do not constitute prima facie discrimination. See generally KHAITAN, supra note 22, ch. 8.

${ }^{38}$ See Sophia Moreau, The Moral Seriousness of Indirect Discrimination, in Foundations of InDiRECT Discrimination LAW (Hugh Collins \& Tarunabh Khaitan eds., 2018). See also Sandy Steel \& Tarunabh Khaitan, Wrongs, Group Disadvantage and the Legitimacy of Indirect Discrimination Law, in Foundations OF INDIRECT DisCRIMINATION LAW (Hugh Collins \& Tarunabh Khaitan eds., 2018).

${ }^{39}$ We are assuming that these neutral rules are not motivated by prejudice or hostility. Such rules would be little more than a pretext for direct discrimination and will be treated by the courts as such.
} 
discrimination is justified, any breach of religious freedom is almost always going to be justified as well.

Difficulty arises in those cases where the two rights do not overlap-i.e. where religious freedom is engaged but there is no prima facie case of religious discrimination. As we saw in the preceding sections, such cases are likely to involve neutral rules that burden religious adherence but do not amount to a disproportionate impact on a religious group (and, therefore, do not constitute prima facie indirect discrimination). ${ }^{40}$. In such cases, it is very difficult for an institution like the judiciary to appropriately balance the publicly intelligible interests of the state (such as its interest in photo driver licenses or in prohibiting open air cremations) and third parties (such as a gay couple seeking rental accommodation) with the committed interest of religious adherents (such as those with a religious objection to being photographed, a religious requirement that they be cremated in the open, or a religious disapproval of gay relationships). A court committed to religious freedom, according to our account, cannot adopt the committed perspective of the adherent itself (were such adoption even possible) - doing so, we know now, is inimical to religious freedom itself. Without the benefit of this committed perspective, however, the court cannot judge the weight or the intensity of the adherent's interests involved. All it can do is check whether the religious freedom claim is plausible, sincere, and accompanied by other rights claims (such as freedoms of expression, movement, association, conscience, privacy, etc.). When these other rights are also involved, the claim will usually be weightier, but only because of the involvement of these other rights. In short, with respect to religious freedom alone, a court has little choice but to assume a significant (but not insurmountable) weight for the claimant's interest in religious (non)adherence. This results to a relatively light-touch approach toward the impugned decision. The result is that religious freedom claims, when not accompanied by discrimination or other rights-based claims, have difficulty in succeeding, especially if non-committal third-party interests are also entangled.

Thus, in a case where (i) religious freedom is infringed by a general law, (ii) not motivated by any animus against a particular religion, (iii) does not simultaneously constitute a prima facie case of direct or indirect discrimination, (iv) significant non-committal interests of the public or of third parties are involved, ${ }^{41}$ and (v) the claimant's other protected freedoms (of expression, etc.) do not demand otherwise, a court should adopt a light-touch deferential review of state action. This is an inevitable consequence of the very vast, subjectively determined, and unpredictable scope of the right to religious freedom-a right that (unavoidably) casts its net so wide must have a shallow bite for the political state to remain functional. We also note that a light-touch approach is not the same as a hands-off approach. Even in these cases, there might be reasons for judicial intervention. After all, while courts cannot weight or appreciate the subjective religious interest of the adherent, they can and must recognize that the subjective interest is a species of the important general interest we all have in our decisional autonomy in matters of religious adherence.

\section{Conclusion}

In our theoretical article published previously, we showed that we have two distinct interests when it comes to matters of religion: an interest in our ability to (not) adhere to our religious commitments and a separate interest in ensuring that our religious group does not suffer relative

\footnotetext{
${ }^{40}$ Justice Sedley found that a neutral ban on all jewelry in Eweida was one such case-it did prima facie infringe upon religious freedom of a worker who wanted to wear a cross, but did not amount to a disproportionate impact on Christians as a group: Eweida v. British Airways Plc. [2010] E.W.C.A. Civ. 80.

${ }^{41}$ See Siegel, supra note 71.
} 
sociocultural, political, or material disabilities in comparison with other religious groups. The protection of these distinct interests is the primary concern, respectively, of the right to freedom of religion and the right against religious discrimination. Building upon these findings in that article, we offered a normative restatement of the law on the two human rights concerning religion. We argued that the scope of the right to freedom of religion is extremely wide, whereas that of the right against religious discrimination is relatively narrow. However, we said, the former right should only be available against the state, whereas it is normatively permissible to apply the antidiscrimination right against some non-state actors. Furthermore, while religious freedom is not engaged when one religious group receives non-zero-sum benefits that do not concern access to basic goods, this may well amount to religious discrimination. We also showed that it is relatively hard to justify discrimination, but relatively easy to justify an act that solely infringes upon religious freedom (i.e. without also affecting other rights simultaneously). Finally, we map the areas where the two rights overlap, and cases where only one of the two rights is engaged. This careful parsing of the two rights brings significant clarity to the politically charged debates on these rights relating to religion. 


\section{University Library}

\section{- M M I N E R VA A gateway to Melbourne's research publications}

Minerva Access is the Institutional Repository of The University of Melbourne

Author/s:

Khaitan, T;Calderwood Norton, J

Title:

Religion in Human Rights Law: A Normative Restatement

Date:

2020

Citation:

Khaitan, T. \& Calderwood Norton, J. (2020). Religion in Human Rights Law: A Normative Restatement. International Journal of Constitutional Law, 18 (1), pp.111-129. https:// doi.org/10.1093/icon/moaa008.

Persistent Link:

http://hdl.handle.net/11343/242043 